\title{
The Use of Brush Management Methods: A Texas Landowner Survey
}

\author{
Urs P. Kreuter, ${ }^{1}$ Heidi E. Amestoy, ${ }^{2}$ Mort M. Kothmann, ${ }^{3}$ \\ Darrell N. Ueckert, ${ }^{4}$ W. Allan McGinty, ${ }^{5}$ and Scott R. Cummings ${ }^{6}$
}

\author{
Authors are ${ }^{1}$ Associate Professor, Department of Rangeland Ecology \& Management, Texas AひM University, College Station, \\ TX 77843-2126; ${ }^{2}$ Teacher, 317 Cecilia Loop, College Station, TX 77845; ${ }^{3}$ Professor, Department of Rangeland Ecology \\ \& Management, Texas A\&M University, College Station, TX 77843-2126; ${ }^{4}$ Regents Fellow and Professor, \\ Texas Agricultural Experiment Station, US Hwy 87 North, San Angelo, TX 76901; ${ }^{5}$ Professor, Texas Cooperative Extension, \\ US Hwy 87 North, San Angelo, TX 76901; and ${ }^{6}$ Assistant Department Head and Assistant Professor, Department of \\ Agricultural Education, Texas A\&M University, College Station, TX 77843-2116.
}

\begin{abstract}
Adoption of effective brush management methods is critical to achieving many rangeland management objectives. However, landowners have often been reluctant to adopt new practices. In April 2000, a questionnaire was mailed to the 1058 landowners in 48 Texas counties to identify factors that influence land management decisions, especially with respect to brush management practices, including Brush Busters treatments. Brush Busters is a Texas-based program developed to expedite the adoption of "select" individual plant treatments through the use of environmentally safe methods. Overall, landowners were "neutral" to "dissatisfied" with regard to the amount of brush on their land. Two primary reasons for wanting to decrease brush were to increase forage production and to conserve water. Kind of brush and cost of brush control were important factors determining the preferred treatment type. In general, the most effective methods were considered to be mechanical treatments for juniper (Juniperus ashei) and individual plant herbicide treatments for mesquite (Prosopis glandulosa) and prickly pear (Opuntia spp.). Mechanical treatments and aerial herbicide applications were perceived to be the most expensive methods, followed by individual plant herbicide treatments, and fire was considered to be the least expensive method. Our study indicated that landowners' satisfaction with Brush Busters' select methods will likely result in an increase in the use of individual plant herbicide treatments for controlling brush. Our study emphasized that a key for enhancing the adoption of sound rangeland management practices is the development and effective dissemination of user-friendly information about low-cost techniques that produce quick results. Easily visible demonstration sites and the establishment of cooperative groups could accelerate the adoption of such practices.
\end{abstract}

\section{Resumen}

La adopción de métodos efectivos de control de arbustos es critica para alcanzar muchos de los objetivos de manejo de pastizales. Sin embargo, muchos propietarios de tierras a menudo han estado renuentes a adoptar nuevas prácticas. En Abril del 2000, se envió por correo un cuestionario a 1058 propietarios de terrenos en 48 condados de Texas para identificar factores que influyen en las decisiones de manejo de los terrenos, especialmente con respecto a las practicas de manejo de arbustos, incluyendo tratamientos de Brush Busters. Brush Busters es un programa con base en Texas desarrollado para acelerar la adopción de tratamientos "selectos" de plantas individuales a través de métodos ambientalmente seguros. En general, los propietarios estuvieron de neutrales a descontentos con la cantidad de arbustos en su terreno. Dos principales razones para querer disminuir los arbustos fueron aumentar la producción de forraje y conservar agua. El tipo de arbusto y costo del control de arbustos fueron factores importantes en determinar el tipo de tratamiento preferido. En general, los métodos considerados más efectivos fueron los mecánicos para el "Juniper" (Juniperus ashei) y el tratamiento de plantas individuales con herbicidas para el "Mesquite" (Prosopis glandulosa) y "Prickly pear" (Opuntia spp.). Los tratamientos mecánicos y las aspersiones aéreas de herbicidas se percibieron como los métodos más caros, seguidos por los tratamientos de plantas individuales con herbicidas y el fuego fue considerado como el método mas barato. Nuestro estudio indicó que la satisfacción de los propietarios con los métodos selectos del programa Brush Busters probablemente resulten En un incremento del uso de tratamientos de plantas individuales con herbicidas para controlar arbustos. Nuestro estudio enfatizó que la clave para aumentar la adopción de prácticas de manejo de pastizales con sentido es el desarrollo de la diseminación efectiva de información amigable para el usuario, información acerca de técnicas de bajo costo que producen resultados rápidos. El establecimiento de sitios demostrativos fácilmente visibles y de grupos de cooperación pudiera acelerar la adopción de tales prácticas.

Key Words: Brush Busters, brush control, information dissemination, landowner participation, rangeland management, technology adoption

Research was funded through a gift to the Dept of Rangeland Ecology \& Management from Dow AgroSciences LLC.

Correspondence: Urs P. Kreuter, Dept of Rangeland Ecology \& Management, Texas A\&M University, College Station, TX 77843-2126. Email: urs@tamu.edu

Manuscript received 19 April 2003; manuscript accepted 29 December 2004. 


\section{INTRODUCTION}

Worldwide there has been a conversion from grasslands and savannas to woodlands (Archer 1989). In Texas, reversal and suppression of woody plant invasions have been attempted for 50 years (Bovey 1998). The recognition that an increase in woody plant cover may affect water yield combined with the fact that rangelands provide the primary water sources for large portions of Texas (TWDB 1990) have led to suggestions that brush control could increase water supplies, groundwater recharge, and spring flow (Thurow et al. 2000). However, the extent to which water yield is affected by brush cover depends on soil and substrate characteristics (Wilcox 2002). Moreover, the recognition that reduction in woody plant cover to below $30 \%$ can lead to habitat loss (Thurow et al. 1997), especially for white-tailed deer (Nelle 1997), has shifted the emphasis from woody plant eradication to integrated brush management (Scifres et al. 1983; Hanselka et al. 1996). However, the conversion of areas with dense brush to patchwork mosaic, savannas, or open grasslands requires sustained intervention (Hamilton and Ueckert 2000). Implementation of brush treatments depends not only on the efficacy of the treatment but also on other factors.

The traditional diffusion model for the adoption of agricultural technology is based on the assumption that agricultural innovation is generated by a centralized institution and then transferred to relatively passive end users in an organized manner (Rogers 1995). Elaboration of this model characterized the act of adoption in socio-psychological terms (i.e. the interaction of social structure, community participation, and communication factors) and led to the notion that landowner decisions to adopt certain innovations represent a general personality trait rather than a distinct act (Fliegel 1993). This led to the categorization of adopters as innovators, early adopters, majority adopters, and late adopters. In addition, experiences leading to a decision to adopt an innovation were grouped into 5 stages: awareness, interest, acceptance, trial, and adoption. The technology diffusion model was also used as the theoretical framework for examining the adoption of integrated pest management practices among Texas cotton growers (Thomas et al. 1990). This study found that information sources produced positive effects on the adoption, with particular groups of producers being more likely than others to use private consultants, chemical salespeople, and group meetings, which significantly affected adoption rates. Face-to-face contact has been found especially to influence later stages of the decision-making process (Fliegel 1993). While the traditional diffusion model seems to have a high level of explanatory power for agricultural production technology, its usefulness for explaining the adoption of conservation practices benefiting future generations has been questioned (Pampel and van Es 1977). Moreover, the adoption of new technology by land managers may be affected by perceived risk and uncertainty (Zepada 1994; Popp et al. 1999), but behavioral factors may be less tangible than physical or economic constraints to adoption (Barao 1992).

A recent study of the adoption of range management innovations among Utah ranchers found that innovation was related to dependence on ranch income, anticipated future of the ranch, extended social networks, and desire to demonstrate land stewardship; conversely, barriers to innovation included inadequate time and resources, peer influences, perceived drawbacks of innovations, spatial characteristics, and political/legal constraints (Didier and Brunson 2004). In the case of brush control, a survey of Texas ranchers found that their decisions were mainly determined by brush cover and that ranchers generally did not intend to treat land with less than $12 \%$ cover, indicating that they had not accepted the need for "maintenance" treatments (Rowan and White 1994). Furthermore, landowner decisions about implementing brush management were influenced by neighbors' perceptions and level of offranch employment (Rowan et al. 1994). Anticipated economic return was the primary determinant for using herbicide or mechanical treatments, while safety concerns were the main reason for not using prescribed fire (Rowan and White 1994). Another study found that quality and quantity of herbage production, livestock management considerations, and projected economic efficacy were the major factors affecting landowners' decisions regarding weed and brush management (Hanselka et al. 1990).

A more recent study pertains to individual plant treatments for brush control, which have become widely accepted. In 2000, Texas County Extension Agents were surveyed to determine their perceptions about the factors influencing landowner interest in Brush Busters (Kreuter et al. 2001). Brush Busters is a Texas-based program initiated in 1995 as a collaborative program of the Texas Agricultural Experiment Station and the Texas Cooperative Extension in San Angelo; the program was designed to expedite the adoption of a "select" group of effective, environmentally safe, and easily applied individual plant treatments for managing woody plants (Ueckert et al. 1999). The program includes treatments for controlling mesquite (Prosopis glandulosa Torr.), juniper (Juniperus ashei Buchholz and Juniperus pinchotii Sudw.), prickly pear (Opuntia spp.) and other cactus species, and huisache (Acacia smallii Isely). The program has resulted in the development of a wide array of information sources, including user-friendly leaflets, training videos and manuals, demonstration sites, and field days. The respondents in the survey of county extension agents indicated that Brush Busters became popular because landowners perceived the recommended treatment methods to be inexpensive, convenient, safe, effective, and predictable brush management treatments and because the program provided user-friendly and readily available information about these methods (Kreuter et al. 2001). The study concluded that, in order to facilitate the adoption rates of ecologically sound rangeland management practices, greater effort should be made to disseminate user-friendly messages about such practices, and these messages should emphasize their short-term efficacy.

Here we report the results of a 2000 survey of landowners in 48 Texas counties. The survey was conducted to more clearly understand those factors affecting landowner decisions regarding brush management and to corroborate conclusions reached by Kreuter et al. (2001) following a survey of county extension agents to obtain information about the widespread adoption of Brush Busters-approved methods. In this study, we use the term "individual plant treatments" to refer to herbicide-based treatments only, while mechanical individual plant treatments (e.g., grubbing and shears) are included in a generic mechanical treatment category. 


\section{METHODOLOGY}

A questionnaire concerning land and brush management was mailed in April 2000 to 1058 landowners in 48 of Texas' 254 counties. Landowners included in the survey consisted of respondents to a 1997 mail survey aimed at soliciting information about the perceived effectiveness of the Texas Agricultural Extension Service in educating and satisfying Texas agricultural producers (Huett 1999). The 1997 respondent group was used because it represented a readily available sample of a broad set of Texas landowners, because resource constraints prevented us from deriving an equally large statewide sample, and because using it allowed us to conduct a time series analysis of some land management parameters (not reported in this manuscript). In the 1997 survey, landowners were randomly selected using county extension mailing lists and lists of landowners with agricultural exemptions. The selected counties consisted of a stratified randomized sample of all Texas counties except those in east Texas, which were excluded because they contain minimal rangelands. Stratification was based on a $4 \times 4$ matrix consisting of 4 geographical regions (north, south, eastern/coastal, and west) and 4 categories of rangeland-based extension programs (no significant rangeland programs, grazing management programs only, brush management programs only, and both grazing and brush management programs). Three counties were then randomly selected from the counties assigned to each cell in the 4 $\times 4$ matrix, resulting in 12 counties with grazing programs only, brush programs only, no programs, and both grazing and brush programs.

Our survey was administered using a 4-step mailing procedure (Dillman 2000). The initial questionnaire and cover letter were mailed on 28 April 2000, followed by a reminder card 10 days later, a reminder letter and second questionnaire on day 21, and a final reminder card on day 28. Survey responses were accepted for analysis until the end of June 2000.

Areas of inquiry included landowner demographics, amount of satisfaction with current brush cover, and perceptions about alternative brush management techniques, including "Brush Busters" approved methods. Levels of satisfaction were determined using a 5-point scale, in which $5=$ very satisfied, $4=$ somewhat satisfied, $3=$ neutral, $2=$ somewhat unsatisfied, and $1=$ very unsatisfied. Similar 5 -point scales were used to determine respondents' perceptions regarding, for example, the efficacy and expense of alternative brush treatments.

Response data were entered into a Microsoft Access database and analyzed using the Statistical Package for the Social Sciences. Statistical methods and parameters used to analyze and report the data include frequency distributions, sample means, $95 \%$ confidence limits, and bivariate correlation coefficients (Spearman's rho, $r$ ). Based on Davis' (1971) terminology, which is used to categorize the degree of association between variables, we assume correlation coefficients of $\geq 0.3$ to represent a meaningful relationship.

\section{RESULTS}

The original 1997 list of landowners did not constitute a random sample of all Texas landowners because it was selected from extension service mailing lists. In addition, not all participants in our survey returned completed questionnaires, and we were not able to contact nonrespondents to conduct a response bias analysis. Therefore, we cannot generalize the results of our study for all Texas landowners. Despite their lack of extrapolative power, the results of our survey cover a wide range of landowners and provide results that are consistent with our previous statewide county agent survey (Kreuter et al. 2001).

Of the 1058 questionnaires mailed to landowners, 528 $(50 \%)$ usable questionnaires were returned. Some survey questionnaires were returned to us because the addresses of participants were no longer valid because the mailing list was 3 years old. In addition, some respondents returned substantially incomplete questionnaires $(>20 \%$ of questions not answered), which were excluded from the analysis. Despite this precaution, the response rate was not identical for all questions. For example, the tabular format used to solicit information about the general effectiveness, cost, and information availability of brush control methods for mesquite, juniper, and pricklypear in some cases resulted in $40 \%-80 \%$ missing data or "don't know" responses. In such cases, summary data are reported for definitive responses, together with the $n$ values used to derive them.

\section{Respondent Demographics}

The respondents $(n=504)$ were generally over 50 years old (50\% selected the 50-69 years category and $32 \%$ selected the over-70 years category), which is consistent with the findings of other landowner surveys (Jackson-Smith et al. 2004; Kreuter et al. 2004; Olenick et al. 2004). Most $(88 \%)$ of the respondents $(n=518)$ were male, and $74 \%(n=510)$ indicated that they had over 20 years of ranching experience. On average, our respondents also had a high level of formal education, with $70 \%$ having at least some college training and $47 \%$ having obtained a university degree.

When asked where they lived, $53 \%$ of the respondents $(n=518)$ stated they lived on a farm/ranch. In addition, $65 \%$ of the respondents $(n=404)$ indicated that they earned over $\$ 50000 /$ year, more or less evenly distributed among the $\$ 50000-\$ 75000, \$ 75001-\$ 100000$, and $>\$ 100000$ categories, which was consistent with another Texas landowner study (Olenick et al. 2004), and there was a positive association between total income and property size $(r=0.38, n=398$, $P \leq 0.05)$.

On average, respondents $(n=396)$ reported receiving 30\% of their household income from off-ranch employment, with level of off-ranch income having a negative association with property size $(r=-0.39, n=379, P \leq 0.05)$. In addition, an average of $16 \%$ of off-ranch income came from off-ranch investments. In terms of on-ranch income, livestock production contributed the largest portion of total income $(24 \%)$, followed by farming $(9 \%)$, and mineral/gas leases $(6 \%)$. Only $4 \%$ of household income was generated from wildlife enterprises, possibly because only about a quarter of the counties surveyed are located in important wildlife areas of Texas. The proportion of income from livestock production, wildlife, and on-ranch mineral/gas leases were all positively related with property size $(r=0.35, n=388 ; r=0.43, n=385 ; r=0.37, n=384$, respectively; $P \leq 0.05$ ). 


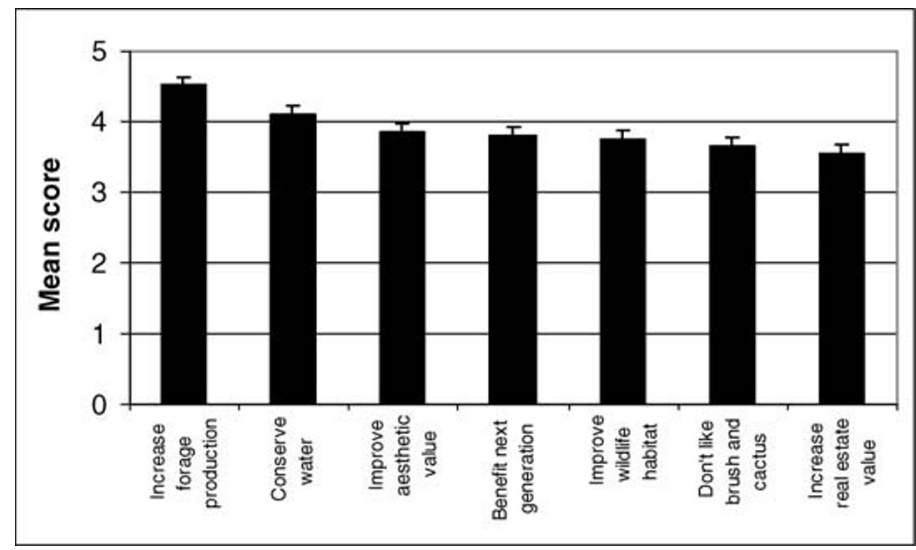

Figure 1. Importance of brush management objectives when considering application of brush control on property $(5=$ very important $\ldots 1=$ not important; dispersion bars represent $95 \%$ confidence interval [CI]).

\section{Brush Control Considerations}

A primary objective of our study was to determine those factors affecting decisions regarding brush control. Using a 5-to-1 scale ( $5=$ very satisfied . . . 1 = very unsatisfied), landowners were asked to indicate their level of satisfaction with the amount of brush on their property. Overall, the mean response score was $2.7 \pm 0.12$, indicating that, on average, respondents were neutral to somewhat dissatisfied with the prevailing amount of brush. Level of satisfaction was negatively correlated with percent cover of mesquite, juniper, and prickly pear $(r=-0.43$, $n=420 ; r=-0.33, n=294 ; r=-0.32, n=374$, respectively, $P \leq 0.05$ ), indicating that landowners became increasingly dissatisfied as brush density increased, regardless of species. However, the level of landowner satisfaction with the amount of brush on their property was also negatively associated with property size $(r=-0.31, n=519, P \leq 0.05)$, suggesting that larger-property owners were less satisfied with the amount of brush on their land than were owners of smaller properties.

To understand reasons for their level of satisfaction with the amount of brush, the survey participants were asked to rank the importance of 7 brush management objectives when considering whether to reduce brush on their property (Fig. 1). The highest

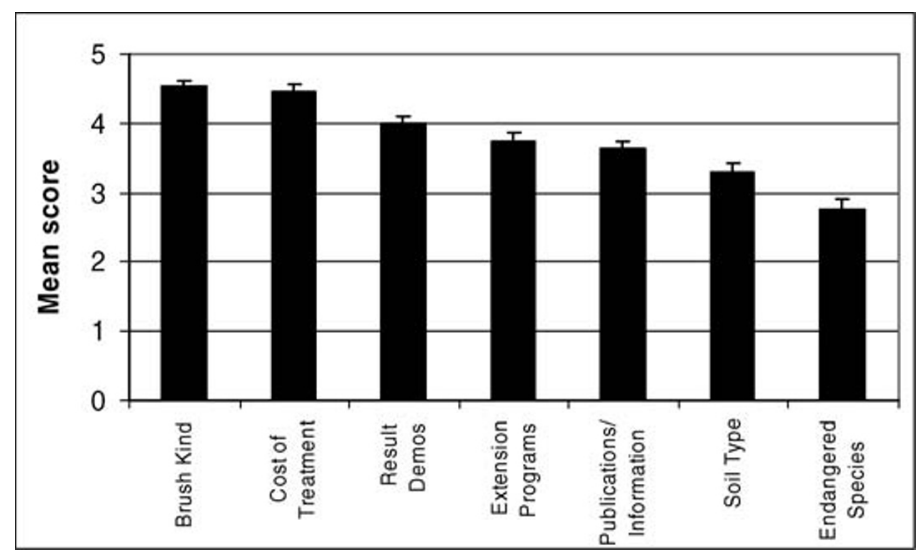

Figure 2. Importance of factors affecting landowner choice of type of brush treatment $(5=$ very important $\ldots 1=$ not important; dispersion bars represent $95 \%$ confidence interval $[\mathrm{Cl}]$ ).

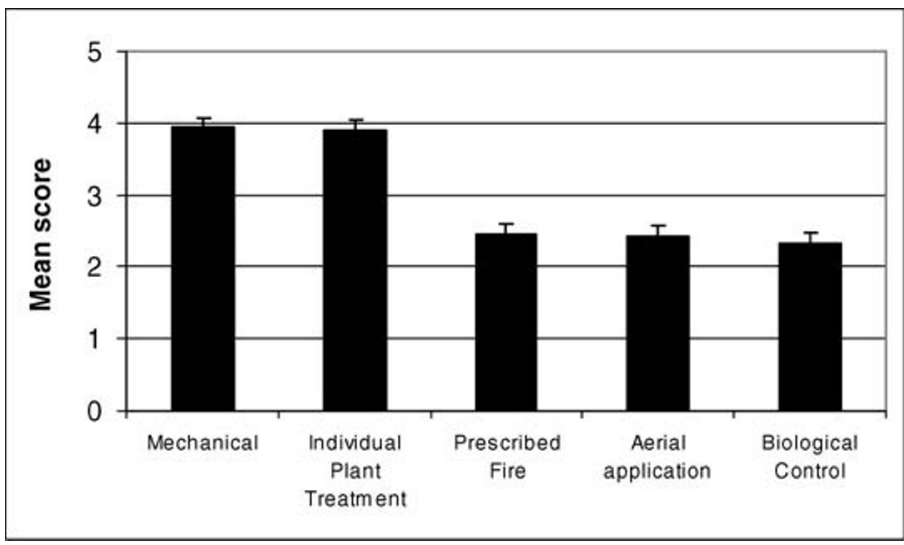

Figure 3. Importance placed by landowners on different categories of brush management ( $5=$ very important . . $1=$ not important; dispersion bars represent $95 \%$ confidence interval $[\mathrm{CI}]$ ).

ranked objectives were increased forage production, followed by water conservation, both of which were ranked as important to very important $(4.5 \pm 0.05$ and $4.1 \pm 0.12$, respectively). The mean response values for the other 5 objectives lay between 3 and 4 , indicating that they were perceived to be neutral to somewhat important in affecting landowner brush management decisions.

Survey participants were also asked about the importance of 7 factors that might affect their choice of type of brush treatment (Fig. 2). Kind of brush, cost of treatment, and demonstrated result were reported to be important to very important $(4.5 \pm 0.08,4.5 \pm 0.09$, and $4.0 \pm 0.11$, respectively), compared with soil type and endangered species, which were considered to be of only average importance $(3.3 \pm 0.12$ and $2.8 \pm 0.15$, respectively), possibly because landowners are unaware of the soil types on their land and do not have endangered species on their land or do not want to manage "around" them. Publications and extension programs were deemed to be average to important in influencing their decisions.

A third aspect that survey participants were asked to address was the importance they placed on 5 categories of brush management methods (Fig. 3). The mean importance scores of mechanical and individual plant treatments were identical $(3.9 \pm 0.13)$ and were substantially greater than aerial herbicide applications, prescribed fire, and biological control $(2.4 \pm 0.15$, $2.4 \pm 0.14$, and $2.3 \pm 0.14$, respectively), which were all considered to be of below-average importance.

\section{Perceptions About Brush Treatment Methods}

To further determine landowners' perceptions about alternative brush management practices, survey participants were asked to indicate the general efficacy, per-acre cost, and information availability of brush control methods for mesquite, juniper, and prickly pear. The categories of treatments included in this area of inquiry were limited to mechanical, aerial spray, individual plant treatments, and prescribed fire. No results are presented for aerial spray for juniper because this approach is not used.

About three-quarters of the respondents rated mechanical treatment as above average in terms of effectiveness for controlling juniper $(73 \%, n=200)$ and individual plant treat- 


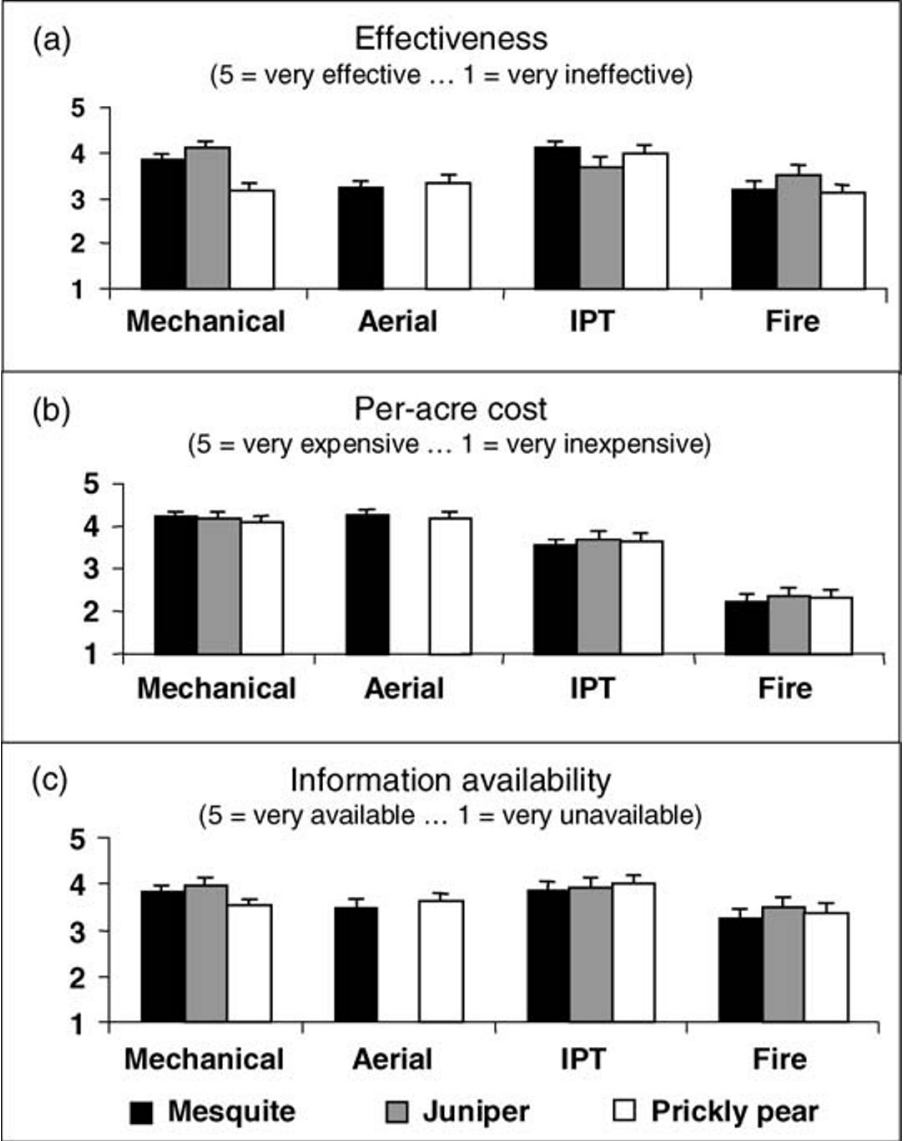

Figure 4. Perceptions of respondents regarding a) treatment efficacy, b) per-acre cost, and c) information availability of 4 treatment categories for mesquite, juniper, and prickly pear (IPT, individual plant treatment; dispersion bars represent 95\% confidence interval [CI]).

ments as above average for mesquite $(77 \%, n=185)$ and prickly pear $(74, n=145)$, while a majority also ranked mechanical treatment as above average for mesquite $(64 \%$, $n=308)$ and individual plant treatments for juniper $(63 \%$, $n=110$ ). A majority of people rated the effectiveness of aerial spraying as above average only for prickly pear $(51 \%$, $n=141$ ), while fire was considered to be equally effective for juniper $(52 \%, n=124)$. The responses resulted in mean effectiveness scores presented in the top panel of Figure 4 in which " 3 " represents average effectiveness. Overall, landowners rated fire as the least effective form of treatment for all 3 species.

When responding to questions about the cost of brush control methods, about three-quarters of the respondents ranked mechanical treatments and aerial herbicide applications as expensive or very expensive for all applicable species (mechanical: mesquite $=76 \%, \quad n=290 ;$ juniper $=75 \%$, $n=179$; prickly pear $=73 \%, n=197$; and aerial spray: mesquite $=82 \%, n=207$; prickly pear $=76 \%, n=144)$. Although about half of the respondents considered individual plant treatments to be equally costly for all 3 species (mesquite $=52 \%, n=179$; juniper $=60 \%, n=104$; and prickly pear $=55 \%, n=137)$, more respondents considered individual plant treatments to be of average expense compared to mechanical treatments and aerial spray, especially for

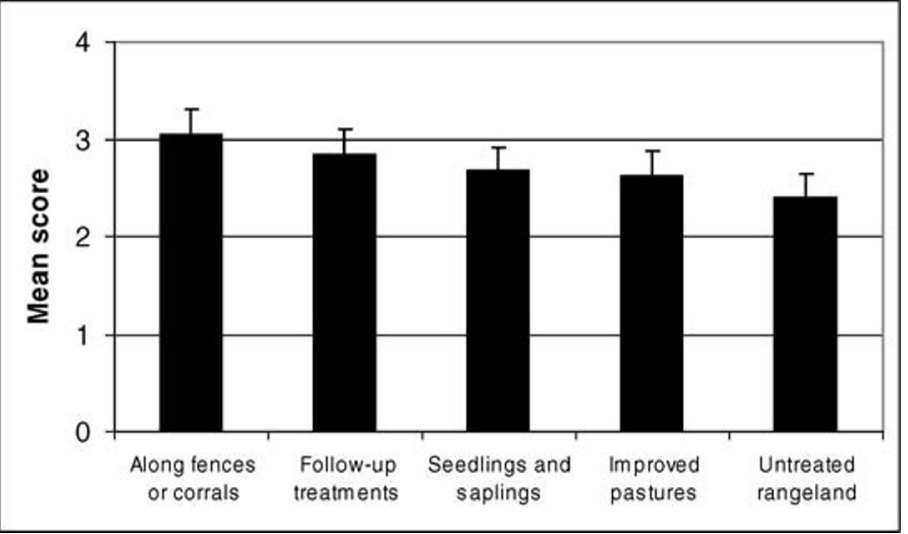

Figure 5. Extent of use of Brush Busters-approved individual plant treatments for alternative purposes ( $5=$ extremely used $\ldots 1=$ not used; dispersion bars represent $95 \%$ confidence interval [CI]).

mesquite and prickly pear. A majority of respondents considered fire to be relatively inexpensive (mesquite $=62 \%$, $n=159$; juniper $=55 \%, \quad n=114$; prickly pear $=54 \%$, $n=130$ ). These rankings resulted in the mean relative cost score values presented in the middle panel of Figure 4.

In virtually all cases a majority of respondents considered information to be of above average availability, except for the use of fire for controlling mesquite and prickly pear, in which case most respondents ranked information availability as average or below average (mesquite $=47 \%, n=216$; prickly pear $=66 \%, n=150)$. As shown in the lower panel of Figure 4, on average, respondents indicated that information about individual plant treatments for all 3 species and mechanical treatments for mesquite and juniper was greater than for all other treatment types. This result can be explained by the wide distribution of information about Brush Busters' select methods that include both chemical and mechanical individual plant treatments.

\section{Brush Busters}

When asked about Brush Busters, 31\% of respondents indicated they knew about the program. Surprisingly, there was no significant difference in the awareness of Brush Busters between counties with brush management programs and counties without such programs. This indicates that in twothirds of the counties surveyed, extension offices were not greatly affecting landowner awareness about Brush Busters, and that in at least some of the counties, more effective landowner education could lead to greater adoption of approved individual plant treatments.

Of the 161 respondents who had heard about the Brush Busters program, $71 \%$ had used individual plant treatments to control brush, while $35 \%$ of the 356 respondents who were unaware of it had used individual plant treatments. This indicates that Brush Busters may have doubled the use of individual plant treatments. Landowners who knew about Brush Busters were asked to use a 5-to- 1 intensity of use scale to indicate the degree to which they used the select individual plant treatments for 5 applications (Fig. 5). On average, no application scored above occasional use. The application that scored highest was "along fence lines or around pens/corrals” (3.0 \pm 0.25$)$, followed 


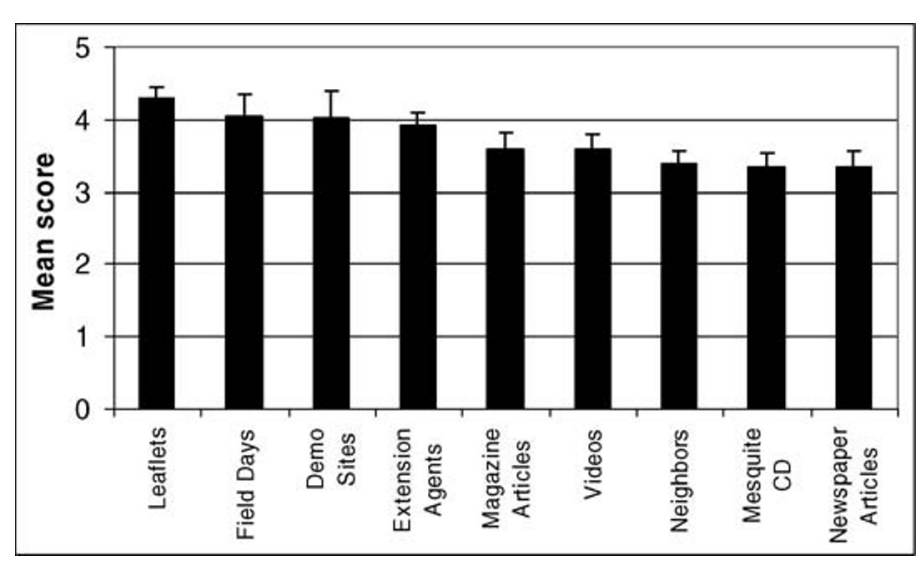

Figure 6. Usefulness of various sources of information about Brush Busters ( $5=$ very useful . . $1=$ not useful; dispersion bars represent $95 \%$ confidence interval $[\mathrm{CI}])$.

by "maintenance in follow-up treatments" $(2.9 \pm 0.25)$. In general, localized or concentrated applications of individual plant treatments therefore appeared to be more common than broad-scale applications on improved pastures and rangelands.

When asked to rank the relative usefulness of various sources of information about Brush Busters using a 5-to-1 scale $(5=$ very useful $\ldots 1=$ not at all useful), on average, respondents ranked the user-friendly leaflets widely disseminated through the Dow AgroSciences mailing lists and by Texas Cooperative Extension highest $(4.3 \pm 0.16)$, followed by field days $(4.1 \pm 0.20)$, demonstration sites $(4.02 \pm 0.19)$, and extension agents $(3.9 \pm 0.21)$, all of which were scored as "useful" (Fig. 6). This emphasizes the importance of laymanfriendly user processes. Other information sources were scored fairly equally at between average usefulness and useful.

Finally, survey participants were asked about their perceptions of the importance of certain aspects of Brush Busters in attracting the attention of landowners (Fig. 7). Again using a 5to-1 scale, participants ranked the selectivity, relatively low cost, and high level of kill of Brush Busters treatments highest $(4.5 \pm 0.13,4.5 \pm 0.12,4.4 \pm 0.13$, respectively), while userfriendliness, availability of information, and the blue dye used as a visual indicator in herbicide mixes were also deemed to be important $(4.2 \pm 0.16,4.1 \pm 0.16,4.1 \pm 0.19$, respectively). The catchy name and logo of the Brush Busters program, which were designed to maximize the marketing impact of the program, were ranked as significantly less important to landowners than the above-mentioned characteristics of approved treatments.

\section{DISCUSSION}

In discussing the preceding results, we focus on 3 issues: 1) tradeoffs in choosing alternative brush management treatments; 2) implications for various stages of the decision-making process; and, finally, 3) implications of landowner self-interest for rangeland management. The discussion and conclusions must be moderated by the limited extrapolative power of our survey results as a result of the uncertainty about the extent to which the respondents represent Texas landowners in general. Despite this limitation, our study provided some interesting

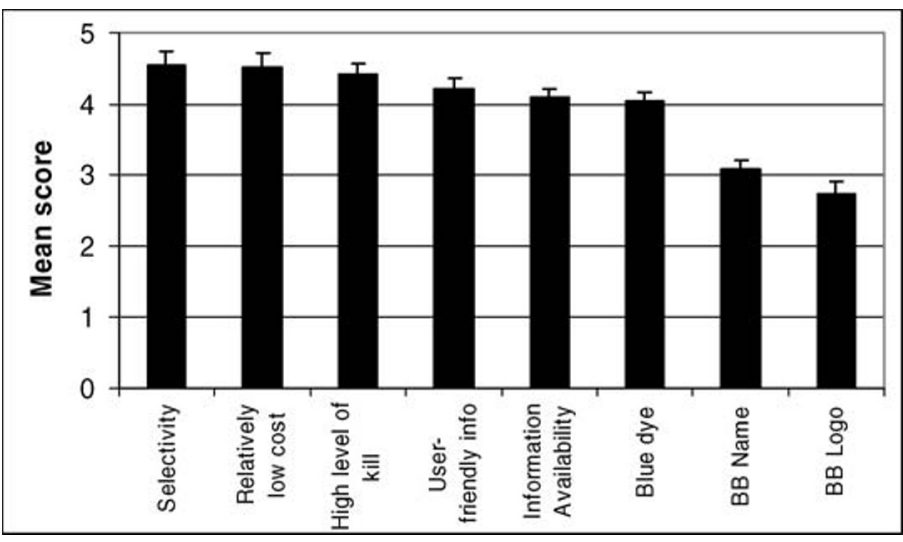

Figure 7. Perceived importance of certain aspects of Brush Busters in attracting the attention of landowners $(5=$ very important $\ldots 1=$ not important; dispersion bars represent $95 \%$ confidence interval [CI]).

observations, which should be explored further using a larger number of counties and a more complete landowner database.

\section{Tradeoffs in Choosing Brush Treatment}

Our results indicate that increasing forage production and conserving water are two of the main reasons for respondents wanting to reduce brush cover in the 48 counties studied. One might have expected wildlife habitat improvement to emerge as a stronger motivator because of the increasingly important economic role of wildlife in Texas and extension efforts to promote selective brush thinning for improving wildlife habitat (Rollins et al. 1997). Given our findings, many Texas landowners may still view broad-scale brush removal more favorably than selective brush thinning, because broad-scale control tends to enhance forage production, and in some cases water supply as well. This has implications for programs aimed at enhancing ecosystem services. For example, ideal woody plant cover for improved water yield, wildlife habitat, and carbon sequestration may differ, which can result in potential tradeoffs among competing programs aimed at enhancing different ecosystem services. Moreover, a landowner survey in the Edwards Plateau of Texas led to the conclusion that, while landowners were interested in brush thinning programs, they were reluctant to participate in programs aimed at increasing woody plant cover to enhance carbon sequestration (Olenick et al., 2004). Such tradeoffs were also reported in an analysis of the interrelationship between carbon sequestration programs and biodiversity, which led to the conclusion that creating economic incentives for carbon sequestration may negatively affect biodiversity (Caparró and Jacquement 2003).

\section{Implications for Various Stages of the Decision-Making Process}

As previously indicated, experiences leading to the adoption of innovations can be grouped into 5 stages: awareness, interest, acceptance, trial, and adoption. Our study provided information about each category.

Awareness. Respondent awareness of alternative brush management methods may be illuminated by their perceptions regarding the availability of information about alternatives. 
Our study found that $70 \%$ of respondents considered information about individual plant treatments to be readily available, even though less than a third knew about the Brush Busters program. In contrast, respondents perceived that there is a relative dearth of information about the use of fire for managing brush, which may explain their lack of appreciation for the role of fire in retarding woody plant proliferation. This finding, together with the widespread use of prescribed fire in central Texas, where burning associations have been established (C. A. Taylor, personal communication, 1999), indicates that educational programs are needed to increase landowner awareness about the ecological importance of fire for maintaining open rangelands. Similar programs may also be necessary for overcoming landowner concerns about using herbicides for managing rangeland vegetation. In addition, while survey respondents did not rank the Brush Busters name and logo highly when asked how important they were in making a decision to implement individual plant treatments, the unique name and logo did facilitate the program's initial recognition (Amestoy 2002).

Interest and Acceptance. Indicators regarding landowner interests in and acceptance of alternative brush management methods include respondent perceptions about treatment efficacy and cost, both of which point to self-interest in investment decisions by landowners, a basic premise of the traditional technology adoption model. Our finding that respondents perceived individual plant treatments to be more effective and less costly than mechanical treatments for both mesquite and prickly pear indicates that landowners would readily adopt individual plant treatments for managing these two species. In contrast, landowners may face a tradeoff when deciding how to control juniper, because respondents perceived mechanical treatments to be more effective but also more costly than herbicide-based independent plant treatments for this species. In practice, the lack of foliar herbicides (vs. soil-applied herbicides) for controlling juniper favors the use of mechanical treatments where such treatments are not prevented by topography (e.g., slopes $<10 \%-15 \%$ ), even though mechanical treatments can be substantially more expensive.

Trial and Adoption. While survey participants were not asked about brush management trials on their own land, visual demonstrations can be used as a proxy for such self-testing. The indication by respondents that the blue dye used in Brush Busters' herbicide treatments is an important factor influencing the adoption of individual plant treatments underscores the importance of visual cues. One aspect to the Brush Busters program is the arrangement of numerous field days to demonstrate the approved methods and the establishment of numerous trial plots on highly visible sites, where the rapid effect of the herbicide treatments was clearly visible (Amestoy 2002). The effectiveness of the Brush Busters program in promoting individual plant treatments was evidenced by the fact that twice as many landowners who had heard of the program had used such treatments to control brush, compared to those who were unaware of it. Our study corroborated the findings of the Kreuter et al. (2001) survey of county extension agents, which indicated that Brush Busters-approved methods have become popular mainly because landowners perceived them to be effective, predictable, selective, inexpensive, convenient, and safe, and because of the ready availability of user-friendly information about these methods.

\section{Management Implications}

Given the apparent association between the perceived treatment efficacy and the ready availability of information about these treatments, respondent perception about the usefulness of various Brush Busters' information sources provide important cues for the promotion of other brush control treatments and, more generally, other rangeland management practices. Respondents ranked the trifold leaflets as most useful (e.g., McGinty and Ueckert 1995, 1996; Ueckert and McGinty 1997), which emphasizes the importance of developing and disseminating user-friendly literature to land managers. Too frequently, research findings regarding rangeland management are not made available to landowners in an easy-to-understand manner, and often when such information is prepared it is not effectively distributed to a wide array of landowners.

The high adoption rate of Brush Busters-approved brush management methods reinforces the positive impact that innovative research and extension activities can have on rangelands when landowner interests and concerns are the focal point. The partnership between the Texas Agricultural Experiment Station, Texas Cooperative Extension, Dow AgroSciences, and Dupont Chemical Company in developing and testing the Brush Busters individual plant treatments and in preparing and disseminating user-friendly information sources provides a good model for programs aimed at enhancing adoption of ecologically sound rangeland management practices.

Brush Busters' focus on simplicity and effective distribution of information to county extension offices, Natural Resources Conservation Service offices, and landowners provides a model for other aspects of rangeland management. One example in which the Brush Busters' approach could be applied relates to the use of prescribed fire. The reluctance of many landowners to use fire in the face of declining property sizes and increasing housing density poses a serious challenge for ecologically sound rangeland management in many rural areas. The collaborative development of a program similar to Brush Busters that focuses on providing accessible information about the importance of fire in managing rangelands and training in the safe use of fire as a management tool is an important first step. A second step would be the expanded involvement of landowners in burning cooperatives, which would facilitate exchange of information, reduce individual landowner risk, and provide on-the-job training that allows landowners to work together and to see results on their own and neighbors' properties.

Our study indicates that the key for success of initiatives developed to improve the adoption of ecologically sound rangeland management practices is to focus on the self-interests and concerns of landowners that systematically address the 5 stages of innovation adoption. This implies increasing landowner awareness and interest, which is gained by developing and disseminating readily available sources of user-friendly information, and increasing landowner acceptance through the establishment of visible demonstration trials that clearly show treatment impacts. As a result of landowner self-interest, rangeland management treatments and practices that provide 
rapid, visible, predictable, and safe responses are likely to receive more rapid acceptance and adoption than those with deferred responses.

\section{LITERATURE CITED}

Amestoy, H. E. 2002. Adoption of Brush Busters and other brush management technologies by Texas landowners [thesis]. College Station, TX: Texas A\&M University. 92 p. Available from: Texas A\&M University, College Station, TX.

ARCHER, S. 1989. Have southern Texas savannas been converted to woodlands in recent history? American Naturalist 134:545-561.

BaRAo, S. M. 1992. Behavioral aspects of technology adoption. Journal of Extension 30:13-15.

Bovey, R. W. 1998. A fifty-year history of the weed and brush program in Texas and suggested future directions. College Station, TX: Texas Agricultural Experiment Station. Bulletin B-1729.

Caparrós, A., and F. Jacquemont. 2003. Conflicts between biodiversity and carbon sequestration programs: economic and legal implications. Ecological Economics 46:143-157.

Davis, J. A. 1971. Elementary survey analysis. Englewood, NJ: Prentice Hall.

Didier, E. A., and M. W. Brunson. 2004. Adoption of range management innovations by Utah ranchers. Journal of Range Management 57:330-336.

Dilıman, D. A. 2000. Mail and Internet surveys: The tailored design method. 2nd ed. New York, NY: John Wiley \& Sons.

FliegeL, F. C. 1993. Diffusion research in rural sociology. Westport, CT: Greenwood Press.

FUHLENDORF, S. D. 1999. Ecological considerations for woody plant management. Rangelands 21:12-15.

Hamilton, W. T., AND D. N. UeCKeRt. 2000. Rangeland brush and weed management: the next millennium; why are we here? In: Proceedings in rangeland brush and weed management: The next millennium, symposium and workshop. College Station, TX: Center for Grazingland and Ranch Management, Texas A\&M University. p 3-13.

Hanselka, C. W., W. T. Hamilton, and B. S. Rector. 1996. Integrated brush management systems in Texas. College Station, TX: Texas Agricultural Extension. Leaflet L-5164.

Huett, B. K. 1999. Is the Texas Agricultural Extension Service succeeding at educating and satisfying Texas agricultural producers? [thesis]. College Station, TX: Texas A\&M University. $164 \mathrm{p}$.

Jackson-Smith, D., U. P. Kreuter, and R. S. Krannich. 2005. Understanding the multidimensionality of property rights orientations: evidence from Utah and Texas ranchers. Society and Natural Resources 18: (in press).

Kreuter, U. P., H. E. Amestoy, D. N. Ueckert, and W. A. McGinty. 2001. Adoption of Brush Busters: results of Texas county extension survey. Journal of Range Management 54:630-639.

Kreuter, U. P., M. R. Tays, and J. R. Conner. 2004. Landowner willingness to participate in a Texas brush reduction program. Journal of Range Management 57:230-237.

McGintY, W. A., AND D. N UeCKeRT. 1995. Brush Busters-how to beat mesquite: a safe and effective three-step way to control mesquite on small or large areas. San Angelo, TX: Texas Agricultural Research and Extension Center. Leaflet L-5144.

McGinty, W. A., AND D. N. UeCKeRT. 1996. Brush Busters-how to master cedar: three safe and effective ways to control small cedar (juniper). San Angelo, TX: Texas Agricultural Research and Extension Center. Leaflet L-5160.

NeLle, S. 1997. Brush as an integral component of wildlife habitat. In: D. Rollins, D. N. Ueckert, and C. G. Brown [eds.]. Proceedings of the Brush Sculp- tors Symposium, 21-22 August, 17-18 September 1997, Uvalde \& Abilene, TX: Texas A\&M University Research and Extension Center, San Angelo, TX. p 3-7.

Olenick, K. L., U. P. Kreuter, and J. R. Conner. 2004. Texas landowner perceptions regarding ecosystem services and cost-share land management programs. Ecological Economics 57:337-345.

Owens, M. K. 1997. Mixed brush ecology. In: D. Rollins, D. N. Ueckert, and C. G. Brown [eds.]. Proceedings of the Brush Sculptors Symposium, 21-22 August, 17-18 September 1997, Uvalde \& Abilene, TX: Texas A\&M University Research and Extension Center, San Angelo, TX. p 43-47.

Pampel, F., JR., and J. C. van Es. 1977. Environmental quality and issues of adoption research. Rural Sociology 42:57-71.

Popp, M. P., M. D. Faminow, and L. D. Parsch. 1999. Factors affecting the adoption of value-added production on cow-calf farms. Journal of Agricultural and Applied Economics 31:97-108.

Rogers, E. M. 1995. Diffusion of innovations. 4th ed. New York, NY: Free Press. Roluins, D., D. N. UeCKert, And C. G. Brown [EDS.]. 1997. Proceedings of the Brush Sculptors Symposium, 21-22 August, 17-18 September 1997, Uvalde \& Abilene, TX: Texas A\&M University Research and Extension Center, San Angelo, TX.

Rowan, R. C., H. W. Laedig, and L. D. White. 1994. Perceptions vs. recommendations: a rangeland decision making dilemma. Journal of Range Management 47:344-348.

Rowan, R. C., AND L. D. White. 1994. Regional differences among Texas rangeland operators. Journal of Range Management 47:338-343.

Scifres, C. J., And W. T. Hamilton. 1993. Prescribed burning for brushland management: the South Texas example. College Station, TX: Texas A\&M University Press.

Scifres, C. J., W. T. Hamilton, J. M. Inglis, And J. R. Connor. 1983. Integrated brush control and grazing management. In: K. C. McDaniel [ed.]. Proceedings of the Brush Management Symposium, Albuquerque, NM. Denver, CO: Society for Range Management. p 89-95.

Texas Water Development Board (TWDB). 1990. Water for Texas: today and tomorrow. Austin, TX: Texas Water Development Board. Document GP-5-1.

Thomas, J. K., H. Ladewig, and W. A. Mclntosh. 1990. The adoption of integrated pest management practices among Texas cotton growers. Rural Sociology 55 : $395-410$.

Thurow, T. L., A. P. Thurow, and M. D. Garriga. 2000. Policy prospects for brush control to increase off-site water yield. Journal of Range Management 53: 23-31.

Thurow, T. L., A. P. Thurow, C. Taylor, Jr., J. R. Conner, and M. Garriga. 1997. Environmental and economic tradeoffs associated with vegetation management on the Edwards Plateau. In: Proceedings of the Juniper Symposium, Technical Report 97-1. San Angelo, TX: Texas Agricultural Research and Extension Center. p 2/3-2/10.

UeCKeRt, D. N., And W. A. McGinty. 1997. Brush Busters-how to take care of pricklypear and other cacti. San Angelo, TX: Texas Agricultural Research and Extension Center. Leaflet L-5171.

Ueckert, D. N., W. A. McGinty, And U. P. Kreuter. 1999. Brush Busters: marketing Prosopis management technology. In: D. Eldridge and D. Freudenberger [eds.]. Proceedings of the 6th International Rangeland Congress, Townsville, Australia; Aitkenvale, Queensland, Australia. p 580-581.

WiLcoX, B. P. 2002. Shrub control and streamflow on rangelands: a process-based viewpoint. Journal of Range Management 55:318-326.

ZEPADA, L. 1994. Simultaneity of technology adoption and productivity. Journal of Agricultural and Resource Economics 19:46-57. 